\title{
Translation and Adaptation in Dissemination of Foreign Literary Works: A Case Study of Robinson Crusoe
}

\author{
Zhou Hongmin \\ College of Foreign Languages, Nanjing Xiaozhuang University, Nanjing, China \\ Email address: \\ hmz1213@126.com

\section{To cite this article:} \\ Zhou Hongmin. Translation and Adaptation in Dissemination of Foreign Literary Works: A Case Study of Robinson Crusoe. International \\ Journal of Language and Linguistics. Vol. 6, No. 5, 2018, pp. 140-147. doi: 10.11648/j.ijl1.20180605.11
}

Received: August 5, 2018; Accepted: September 10, 2018; Published: October 8, 2018

\begin{abstract}
When investigated in a broader vision, adaptation carried out away from translational act can also contribute to transmission of a foreign text. Based on the presumption that the act of translation moves foreign classics into the periphery of target culture, but far from asserting their finality, the author, supported by the case of Robinson Crusoe, singles out translation (retranslation), and adaptation (adaptive translation and post-translation adaptation) for a study, and attempts to explore how they are related to one another and identify their role in contributing to the transmission of foreign text. It is concluded that besides translation and retranslations, post-translation adaptation contributes more share to transmitting and canonizing a foreign text.
\end{abstract}

Keywords: Translation, Adaptation, Roles in Transmitting Foreign Text

\section{Introduction}

It is generally believed that translation and its subsequent translations (retranslations) play an important role in disseminating a foreign text, therefore their importance in this respect cannot be overemphasized or overestimated. Undoubtedly it is the translation that initiates the transmission and popularization of a foreign work. Only after translation will a foreign work be encoded in another language and empowered to travel over time and space to live in another culture and construct a series of cultural and literary values, but this act of translation only constitutes the initial phase of the construction of foreign literary world and its productivity in the target culture. Translation (retranslations) alone cannot ensure its dissemination, vitality and status of canonicity.

If they are looked at in a macro social context, some more factors will make their contribution to the being. Armstrong [1] maintains that not only the translational act is caught up in the polysystem of the target culture's synchronic literary world, but also the translational series begins to constitute its own system, variously advanced by authors, critics, booksellers, teachers, librarians, and readers at large. While he stresses that translational act constitutes the initial step in the construction of the literary world of target culture followed by some other factors, I suggest that far from asserting the finality of a foreign text, translational act begins to constitute and expand its own value, variously furnished by re-translators, adapters, critics, booksellers, teachers, librarians, and readers at large.

With this in mind, the author will, besides translation and retranslation, include adaptation in my topic. In order to distinguish it from the adaptation which is often discussed within the translational process, the author will start henceforth and develop it along to the post-translation adaptation (in the later part sometimes referring to it as rewriting), concerning who adapts, how they do it, under what circumstances, for which audience. Taking translation, retranslation, post-translation adaptation as a continuum in the macro social context, the author will try to explore how they are related to one another and identify their role in contributing to the dissemination of foreign text, and do it by the case study of Robinson Crusoe.

\section{Adaptation Within and Outside Translation}

In translation studies, adaptation is usually examined within the translational process and linguistic transfer, and the boundary between adaptation and translation techniques is not clearly demarcated. Some scholars deem adaptation as one of techniques used in translation. The most influential is Vinay \& Darbelnet's explication [2]. They list adaptation as their 
seventh translation procedure, taking adaptation as a procedure which can be used wherever the context referred to in the original does not exist in the culture of the target text, thereby necessitating some form of re-creation. This widely accepted definition views adaptation as a procedure to achieve equivalence of situations where cultural mismatches are encountered. In terms of mode of adaptation, the procedures used by the adapter can be classified as follows: 1) transcription of the original: word for word reproduction; 2) omission: the elimination or reduction of part of the text; 3 ) expansion: making explicit information that is implicit in the original, either in the main body or in footnotes or glossary; 3 ) exoticism: the substitution of stretches of slang, dialect, nonsense words, etc. in the original text by rough equivalents in the target language (sometimes marked by italics or underlining); 4) updating: the replacement of outdated or obscure information by modern equivalents; 5) situational equivalent: the insertion of a more familiar context than the one used in the original; 6) creation: a more global replacement of the original text with a text that only preserves only the essential messages/ideas/functions of the original. Obviously the so-called adaptation modes practiced in translating process are quite similar to translation techniques for the purpose of producing a target reader-oriented text.

It is true that adaptation is a universal approach to translation in both Chinese and western cultures, but it cannot be so easily defined and quantified as described above. Both subjective and objective factors may make it very elusive, and because of that, besides prescriptive dos and definitions, it is necessary for us to make some descriptive illustrations from a cultural perspective.

The golden age of adaptation was in the seventeenth and eighteenth centuries, the epoch of the belles infideles which started in France and then spread to the rest of the world. The very free translation carried out during this period were justified in terms of the need for foreign text to be adapted to the tastes and habits of the target culture, regardless of the damage done to the original [2].

During the late Qing dynasty the extremely free translation was prevalent for the utilitarian purposes, such as social innovation and enlightenment of the masses. Though we are not certain what happened to some texts, i.e. whether they are produced through the adaptive translation or produced based on the translated texts, the historical figures involved in translation were unanimously of the opinion that adaptive translation should be practiced in order to produce impact on their society. Yan Fu (1854-1921), the pioneer who introduced systematically the western social sciences through translation, often, as he insisted in Translator's Preface of Tian Yan Lun (On Evolution), incorporated comments, developed the idea of the original at his whim, supplemented introduction, reversed the sentences and paragraphs of original [3]. Liang Qichao (1873-1929), a social reformist and famous scholar, suggested that translators should "compose a text by what they have learned from the original," and "delete it, supplement it and alter it wherever they deem it necessary" (Chen, 2000: 100). When starting translation at the turn of the 20th century,
Lu Xun (1881-1936), the literary master cherished by Chinese, practiced liberally adaptive procedures. He admitted that his translation of Voyage au centre de la Terre by Jules Gabriel Verne (translated as Voyage under the Earth) was actually a rewriting, and he claimed the Sparta's Soul, another translated novella, was a plagiary or transcription, but what he really meant is that he could not trace the origin of it as he translated it from Japanese serving as intermediary language and incorporated a considerable amount of his composition [3]. In history, translators (mostly famous writers) would take great liberty with the original, and in order to exert influence on their society they would highlight some aspects and ideas of the original or fuse their ideology and social context to compose a piece of work which could stand alone. As adapted to the needs of readers, adaptive translation is more favorable and potent with audience than genuine translation in spite of its unfaithfulness to the original.

Ever since the last half of 20th century, in spite of the institutionalized translation norms, adaptation approaches have still retained their vitality and have been made to direct at more diversified texts than in the previous ages when religious and literary texts dominated. A case in point is translation of journalism text which involves enormous amount of editing just as an IPS translator-editor described her role in this process as follows [4]:

We decide which notes to translate into English and translate them for the English-speaking market, thinking of this market, of this audience. We add context, re-edit, reorganize the note, we give it a new title. We do a lot of work with the note; it rarely is a direct translation, just as it comes... We even combine notes if there are two or three about a subject when we do not need three notes in English on that subject.

Adaptive translation is also at work with academic writing which may involve data collection and argument alignment from papers in foreign languages. In the process the author may translate some paragraphs as citation for argumentation or defense, but mostly translation does not work well enough, and he has to summarize and condense ideas from these papers for enforcement or argumentation, and still he has to comment and develop these ideas [3]. And in my term this act in academic writing can be called "translation plus" adaptation.

However, if we should confine our discussion of adaptation to translation process, we cannot fully account various versions of some literary canon in the hundreds.

When filling in the search box with “《鲁滨逊漂流记》” (meaning The Drifting Life of Robinson) on duxiu (Chinese academic searching tool which can seek out and show the number of books of the name stored in libraries of China's territory), as many as 654 different versions of the name will pop out. Are they all translations or adaptive translations? Definitely not. Further investigation will show you that they are marked on the front cover as bilingual version, translated plus annotated version, edited version, rewritten version, simplified version, contracted version, excerpted version, summary version, cartooned version, illustrative version, literary review version, screen story, comic story and many 
others while the genuine translations are far and few between. It is concluded that "the foreign-language texts we call 'classics' do not merely attract translation, but eventually, ......become subject to multiple" adaptations (post-translation in my term), "as publishers scramble to transform the cultural capital those texts have acquired into economic capital" [5]. But what is origin of these post-translation adaptations, who contributes these versions and how they operate adaptation? And what function do these versions serve?

To clarify these issues, we have to break away from linguistic transfer of translation and posit our ground on a macro social context to check how it is related to translation, retranslation and how it, along with them, contribute to the dissemination and canonization of a foreign text. In the following, the author will take Robinson Crusoe as a case study for illustration.

\section{Translation, Retranslation: A Case Study of Robinson Crusoe}

It can be concluded that the dissemination and canonization of Robinson Crusoe (popularly called 《鲁滨逊漂流记》 meaning The Drifting Life of Robinson) has gone through more than one hundred years of translation, retranslations, adaptations contributed by translators, re-translators, adapters, rewriters, critics, publishers and readers at large.

It is Shen Zufen, a lame and obscure youngster, who translated it for the first time and had it published in 1902 entitled The Drifting Life on the Isolated Island. In spite of the fact that his translation is a excerpted version, and still he reshuffled the order of chapters and replaced it for the narrative style of Chinese traditional novel, the readership passed it for a genuine translation, and acclaimed it for the pioneering spirit, independence and entrepreneurship of the protagonist he had introduced [6]. The success of this deficient translation should be attributed largely to the social milieu China happened to be, where at the turn of the 20th century the enlightened elites were turning to the West for remedies to save the declining imperial dynasty, and translation of literature, esp. political novel, was taken as an effective tool to enlighten and mold the masses, who for thousands of years, had been cultivated by Confucianism which mainly advocates for loyalty to emperor, fealty to parents, obedience to husbands, and consequently had been tempered to be characters of docility and servility, taking things as they were and making no attempt to change what they were. Traditional Chinese novels, if any, mostly exalt the romance between young scholars and pretty girls, service of ministers to emperors, deity of ghosts and demons. Under this circumstance the pioneering spirit embodied in the work was undoubtedly enlightening and inspiring. "Though disabled, the translator persisted in the work which should awaken 400 millions of Chinese," commented Gao Fengqian, editor of the translation in his preface, and Song Jiaoren (1882-1913), one of the founders of the Republic of China, after reading the translation, pointed out, "the character's boldness to take risks and persistence through adversities can serve as a cure to those stubborn conservatives who are still addicted to feudal ideology" [6] .

While the initial translation of a foreign text, whether it is in the form of genuine translation, or adaptation, or excerption, may influence the value system of target culture, the established ideology, literary tradition will likely shape and decide on the forms of the text. As Venuti [5] put it,

In contributing to the canonicity of a foreign text, the translation leaves neither that text nor the receiving situation unaltered. The foreign text undergoes a radical transformation in which it comes to support a range of meanings and values that may have little or nothing to do with those it supported in the foreign culture.

Since its first translation in 1902, retranslation and adaptation have come out one after another spanning over a century to "support a range of meanings and values that may have little or nothing to do with those it supported in the foreign culture." It was first retranslated with more chapters added by Lin Shu (1852-1924, a famous scholar and legendary translator who knows nothing of any foreign language but translates more than 180 novels and dramas with the help of his collaborators), and his collaborator Zeng Zonggong and published in 1906. Up to the 1940s it had been adapted by Li Lei, Gao Xisheng, Peng Zhaoliang, Gu Junzheng, Tang Xiguang, Yang Jinsen, Zhang Baoxiang, Xu Xiacun, Fan Quan and compiled into various novel series and course book series. From 1931 to 1948 , as many as 11 single issue versions of retranslation had been turned out by such famous translators as Gu Junzheng, Wang Yuanfang, $\mathrm{Xu}$ Xiacun, and many other obscure translators, among which Gu Junzheng \& Tang Xiguang's version was published 13 times from 1934 to 1948 while Fan Quan's contracted version was published three times within the year of 1943 [6].

After the founding of the People's Republic of China, Xu Xiacun's version was published again in 1959, followed by Guo Jianzhong's retranslation published in 1996 by Yilin (Translation Clusters) Press, and Huang Gaoxin's retranslation in 2006 by Shanghai Yiwen (Translated Text) Press and hundreds of less-known retranslations and adaptations [6].

Obviously, such craze for Robson Crusoe is attributed to the joint work of re-translators and adapters, readers, publishers. And these multiple texts derived from Robinson Crusoe speak for the fact that once transcending over time and space through translation to another culture, the foreign text through retranslations and adaptations in the receiving situation has produced a range of meanings and values of independence, exploration, adventurousness, initiatives, survival skills which should be developed to instill and inspire the youngsters.

As far as retranslation is concerned, translation scholars have raised different hypothesizes, but they are mostly extrapolated from the translation itself, not scrutinized against canonization of text. Berman argued that translation is an 'incomplete' act and that it can only strive for completion through retranslations [7]. Xun Jun [8], a well-known Chinese 
translation scholar, maintained that one translation is one interpretation of the original. This implies retranslation will deliver a meaning different from the previous ones, but a comparison of different versions will render the hypothesis groundless. While retranslation may present a different version in expression and style, it rarely does in content and meaning. For instance, after comparing three retranslations of the paragraph in which Father gave Crusoe "serious and excellent counsel against what he foresaw was my design" [9] the author found that all of them keep the content intact except the style of expression and deliver the same tenor that Father suggested the middle state of life was best, and Crusoe should not go to sea for adventure.

A second aspect of the retranslation hypothesis pertains to the issue of ageing. Berman suggests that while originals remain forever 'young', translations will age with the passage of time, thus giving rise to a need for new translations [7] . Lu Xun argued that as language tends to change with the passage of time, new translation would be turned out accordingly, and not surprisingly seven or eight retranslations would turn up in the future [10]. However, the ageing of language is so slow that readers can hardly be aware of it within a certain span of time. It took nearly one hundred years for the vernacular Chinese to break away from classical Chinese and establish itself as writing norm, and it is justifiable for us to retranslate Robinson Crusoe done by Shen Zufeng and Lin Shu because their classical Chinese versions are out of date. But the language ageing postulate cannot account for the reason why so many retranslations have emerged ever since the 1919 May Fourth Movement when the Chinese vernacular language has not changed so much. This can be illustrated by the following two versions of the passage in which Crusoe's father tries to reason him out of his desire to go to sea.

He bid me observe it, and I always should find, that the calamities of life were shared among the upper and lower part of mankind; but that the middle station had the fewest disasters, and was not exposed to so many vicissitudes as the higher or lower part of mankind; nay, they were not subjected to so many distempters and uneasiness either of body and mind as those who, by vicious living, luxury, and extravagances on one hand, or by hard labor, want of necessaries, and mean or insufficient diet on the other hand, bring distempters upon themselves by the natural consequences of their way of living; [9]

Version 1):

他叫我注意到上层社会和下层社会同样会碰到生活中 的苦恼和不幸; 而处于中间地位的人就很少有这些灾难, 同时也不像上层社会和下层社会那样在生活上忽起忽落, 变化无常。不仅这样, 中等阶级既不像那些阔人一样, 由 于过着骄奢淫逸弄得身心交瘁; 也不像那些穷人一样, 由 于过着终日劳苦，少吃少穿的生活而搞得憔悴不堪。 [11] Version 2):

他嘱咐我说, 只要我留心观察, 我就会发现, 不论上等 人和下等人，他们在生活中都有灾难和不幸，而中间阶层 的人却很少有这种不幸, 也不会经受他们那种枯荣盛衰的 无常变化; 不但如此, 中间阶层的人还不会遭受到像那些 阔佬因耽于骄奢淫逸、挥霍浪费的不道德生活而遭受到的
许许多多精神上的忧虑和不安, 也不会遭受到像那些劳苦 大众因终年劳累、缺衣少食而自然造成的疲劳和困乏。 [12]

The above two versions span over seventy years in which $\mathrm{Xu}$ Xiacun's version came out in the 1930s and the Tang Yinsun's in 2010. Seventy years of time should have distinguished them from each other in language, but on the contrary Xu Xiacun's version seems to be more smooth and fluent to modern readers because of its more idiomatic Chinese.

Therefore, "no straightforward link can be assumed to exist between the passage of time and the need for retranslation since there are many cases of retranslations of the same source texts undertaken within a short span of time. The decision to retranslate or to publish a retranslation, then, cannot be reduced to a single factor such as the ageing of the initial translation" [7].

Since factors of incomplete translation, interpretation, language ageing cannot fully account for retranslation, it should be concluded that there is a complex interaction between retranslation and the previous translation in which re-translator will, on the one hand, take the previous one as a starting point to save the mental labour of comprehending all over and inherit its merits, while on the other hand he claims his version is better than the old one(s) for he assumes he has rectified the latter's errors and update his/their language style. In a word re-translators will likely justify their act in one way or the other, just as Guo Jianzhong [13], one of re-translators of Robinson Crusoe, advised in his Translator's Preface, "besides updating its language, re-translators should draw upon the predecessors' translation and the findings of scholars to improve the previous ones."

Unfortunately, in this relay of translation, however hard re-translators tried to make their translation prominent by repressing their predecessors, they will eventually be overshadowed by their successors, and all their work only contributes to a more and more immortal Defoe and his Robinson Crusoe, rather than an immortal translation of Robinson Crusoe produced by somebody. In other words, retranslation can help the reading public recognize Daniel Defoe as literary master and Robinson Crusoe as masterpiece, but not re-translator as master translator and his translation of Robinson Crusoe as master translation, "A masterpiece will last forever, but its translation won't, even the greatest translation produced by some great translator won't" [14]. The master translation stays with translation scholars, translation critics, and translation learners.

\section{Post-translation Adaptation: Motivation and Strategy Beyond Robinson Crusoe}

Since these re-translators" act "is not the sole locus of culture" [1], since these differential retranslations cannot fully control both readers at large and readers in particular, publishers in collaboration with rewriters take their place to 
control these readers, especially in the internet age when the populace is accustomed to scan reading, flash reading, cursory reading, picture reading, few would care to immerse himself in reading genuine translation. While the genuine translation, like classics, is so time-consuming and difficult to digest, rewriting business with the slogan of disseminating culture by relieving the burden of digestion has come into being and is booming more ever than before, and with so many versions of retranslations, who would care to adaptively translate the original?

Historically, "rewriters have always been with us" [15]. In the western tradition, Lefevere [15] summed up what rewriters did as follows:

From the Greek slave who put together anthologies of the Greek classics to teach the children of his Roman masters, to the Renaissance scholars who collated various manuscripts and scraps of manuscripts to publish a more or less reliable edition of a Greek or Roman classic; from the seventeenth-century compilers of the first histories of Greek and Latin literature not to be written in either Greek or Latin, to the nineteenth-century critic expounding the sweetness and the light contained in works of classical or modern literature to an increasingly uninterested audience; from the twentieth-century translator trying to "bring the original across" cultures, as so many generations of translators tried before, to the twentieth-century compiler of "Reader's Guides" that provide quick reference to the authors and books that should have been read as part of the education of the non-professional reader, but go increasingly unread.

But in Chinese tradition, i.e. before the end of Qing dynasty, scholars rewrote mostly about literary classics of their own heritage, rarely about translations from foreign source. Because of their canonicity, the Four Books and Five Classics of Chinese heritage have attracted thousands of scholars who through interpretation, annotation and adaptation have created lots of surplus meanings and values for each generation which are far apart from those intended by the original writers.

Generally speaking, the more canonical the text has become, the more appealing it is to rewriters who would interpret, annotate, adapt and reshape it. The law is also applicable to the rewriting of translation. As in rewriting of classics, the motive for rewriters to pick up a translated work for adaptation is the popularity/canonicity of a work in the receiving culture, while the popularity of a translation is largely attributed to the extent to which it is put to use in publication, adoption in textbook and anthology, literary review and some other media, such as TV and internet. When deciding on which of so many translated versions to be adapted, these rewriters are not as picky about the quality of translation as we are expecting. They won't care so much as to whether the version is faithful to the original in content, equivalent to the original in form and style. In his agenda, the version is no more than the manuscripts to start with because he is going to disrupt and reshuffle the translation in his own way and in compliance with the requirements of publishers. What he concerns about is audience, how to attract audience, rather than translation and its translator.
Therefore, rewriters or and their publishers will first of all assess the potential readership and categorize them according to their demands, tastes and likes. Generally speaking, rewriting of translation is directed at the following groups: 1) Teenagers who take to adventurous stories, science-fictions, detective stories, rewriters will usually focus on one aspect of the work and fit it into an excitingly and engagingly story of uniformity by repressing plural meanings and literary devices. Maybe the adapted Robin Crusoe is meant to instill in teenagers pioneering spirit, human's power over adversity and so on, instead of exploration and colonization of the burgeoning capitalism in the 17 th century Britain. Readers may be impressed by the naughty and adventuresome aspect of the character of the adapted The Adventures of Tom Sawyer rather than criticism and ridicule on the hypocrisy and cynicism of the 19th America. What is left in the adapted Mob Dick is the breath taking description of the fight between Captain Harper and whale, with all the mystical elements gone. 2) Second language learners who want translation to help interpret the original, the adapted version is not entirely in Chinese, but in bilingual form for the convenience of language learners, with the left side in foreign language, mostly English, and the right in its Chinese equivalent, or the top in foreign language, and the bottom in its Chinese equivalent. Edition of the kind is not the complete and genuine form of the original and its Chinese equivalent, but excerpted and simplified original and its translation or several chapters included in some anthology of foreign literature and their translation, whose content, structure, and style usually closely follow those of the original for the sake of learners. 3) Professional readers for specific purpose, the book is usually in the form of compilation of knowledge of foreign literature, including authors, social background, their works, introduction to their works, their meanings, at times some translated passages inserted and illustrated by specialists, but readers are usually kept in the dark about the source of these translated passages. For compilers there is no point of referring to translators and commenting on their translation. What compilers of such Reader's Guides try to do is to "provide quick reference to the authors and books that should have been read as part of the education of professional readers, but go increasingly unread." Translations in these books are meant to provide a further insight into foreign works for professional readers whose purpose of reading may be instrumental, such as for test, for academic writing. 4) Readers at large, rewritings are not intended for any particular group, but they should be so designed as to arouse the interest of readers at large who care to read when they afford the time.

Rewriters and publishers will take great pains to cater to readers. In designing the format of rewriting, publishers will try every means to stir up the interest and enthusiasm of audience, typified by the following devices: 1) hawker-like advertisement slogans on the cover; 2) prefaced by rewriters or editors; 3) prefaced or complimented by celebrities; 4) fanciful design, such as illustration through pictures, comics, film photos.

The key to rewriting lies in the adaptation of language 
oriented to audience. The whole text is made to be simplified, lucid and accessible. It is achieved by reshuffling those awkward, cumbersome translationese that is often found in translated text, cutting out/replacing with a few transitional words for those long passages that may get a plot or character too far to bore readers or may be irrelevant to modern situations, relocating passages according to the adapter's logic, augmenting the text with expressions popular in the receiving culture, such as internet buzzword, colloquialism, slang, elucidating foreign ethics and values from the standpoint of Chinese culture, as is “好男儿志在四方, 留在家里有什么意 思? ”(A good boy should aim high, and what's the point of staying at home?) in Zheng \& Zhang Bo's version [16]. Take the first paragraph of Robinson Crusoe, for example, while the origin of the protagonist is fully rendered in translated version, in the rewritten versions, it is made to be simple and fluid in one way or another.

Original text:

I was born in the year 1632 , in the city of York, of a good family, though not of that country, my father being a foreigner of Bremen who settled first at Hull. He got a good estate by merchandise and, leaving off his trade, lived afterward at York, from whence he had married my mother, whose relations were named Robinson, a very good family in that country, and from whom 1 was called Robinson Kreutznaer; but by the usual corruption of words in England we are now called, nay, we call ourselves, and write our name"Crusoe,"and so my companions always called me. [9]

Translated version:

$$
\text { 一六三二年, 我生在约克市一个富裕家庭。我们不 }
$$
是本地人。父亲是德国不来梅市人。他移居英国后, 先住 在赫尔市, 经商发家后就收了生意, 最后搬到约克市定居, 并在那儿娶了我母亲。母亲娘家姓鲁滨孙, 是当地的一家 名门望族, 因而给我取名叫鲁滨孙・克罗伊茨内。由于英 国人一读“克罗伊茨内”这个德国姓, 发音就走样, 结果大 家就叫我们“克罗索”, 以致连我们自己也这么叫, 这么写 了。所以，我的朋友们都叫我克罗索。

\section{Rewritten versions:}

1)我的父亲是德国人，他年轻的时候来到英国胡尔城 赚下了一份家产, 后来就搬到约克城, 娶了我母亲。一六 三二年母亲生下了我, 因为母亲的娘家姓鲁滨逊, 父亲就 给我起了鲁滨逊・克鲁索这个名字。

Back translation:

My father was a German. He came to Hull of Britain when young and earned a good estate. He later moved to York and married my mother who gave birth to me in 1632. Because my mother's relations were named Robinson, my father named me Robinson Crusoe.

2) 我的名字就叫鲁滨逊・克鲁索, 1632 年出生在英国 约克市一个中产阶级的家庭。我父亲原本是德国布莱梅人, 后来，他到英国来经商，经过多年的努力，才挣了一份不 错的家产并在约克市定居下来。我的母亲美丽而又善良,
是当地一户富裕人家的女儿。

Back translation:

My name is no other than Robinson Crusoe. In 1632 I was born into a middle class family of York city in Britain. From his birthplace of Bremen of Germany, my father came to Britain as a merchant, and after many years of effort, he had earned a good estate, and ever since lived at York. My mother is kind-hearted as well as pretty looking. She came from a wealthy family of York.

3) 我叫鲁宾逊, 1632 年出生在英国的约克城, 我是 家里三兄弟中最小的一个, 也正因为如此, 我从小就十分 调皮任性, 我行我素的, 所以我也是家里最令父母亲头痛 的一个。 [18]

Back translation:

My name is Robinson. I was born in 1632 in York city of Britain. Being the youngest of three brothers of my family, I grew up to be wayward and naughty, doing everything as I wanted, thus causing the greatest pang to my parents.

In the period in which classics give way to the rewritten versions in transmission of values, and few readers would immerse themselves in reading a classic until to the last chapter, rewriters take the place of their writers and translators to continue the mission of disseminating their values and meanings for those who take to cursory reading, skipping reading, gist reading, compulsory reading, fragmentary reading, browsing reading, instrumental reading. As the classics of one's own heritage, foreign literary works after translation and retranslations are made subject to multiple post-translation adaptations, thus contributing all the more to their canonicity. And the case of Robinson Crusoe can fully illustrate the point.

\section{Conclusion}

It is concluded through the case study of Robin Crusoe that besides translation and its subsequent translations (retranslations), post-translation adaptation contributes its share to transmitting and canonizing a foreign text, and even more in our society today. Robinson Crusoe has gone through more than one hundred years of translation (retranslation), adaptation (adaptive translation and post-translation adaptation), in which, while its continuous translation (retranslation) can contribute to an ever more immortal Robinson Crusoe and Daniel Defoe, its dissemination is more dependent on the post-translation which covers versions of simplification, abridgement, bilingualism, localization and the like, thus augmenting and increasing the value and meaning of the original. Unlike the adaptation which is often discussed in translation, especially advanced by Vinay \& Darbelnet, post-translation adaptation is the one in which publishers in collaboration with rewriters perform a series of procedures on translated text, sometimes on the previous rewritten text whose source is ultimately translation. While they have nothing to do with translational acts, these rewritten versions are heavily dependent on the translated product. Hence they 
are both related to and distinguished from each other in that temporally, translated text appears before the rewritten as two distinct texts, and translator precedes rewriter as two distinct inconsecutive individuals as opposed to that of adaptive translation in which translator performs translation and adaptation at the same time. In a word, without translation (retranslation) adaptations in the form of simplified version, abridged version, contracted version and the like would be impossible. Just because it may share with adaptive translation the character of fluency, simplicity and accessibility of text, and stands more or less for the original, post-translation adaptation is often accepted by general readership as adaptive translation, but it is incorporated with more freewill writing elements than adaptive translation, therefore should be taken as rewritings irrelevant to translational act, otherwise it will be labeled as notorious reputation of plagiarized, faked, defective translation.

Post-translation adaptations are not as faithful to the original as adaptive translation, let alone genuine translation, but when publishers "scramble to transform the cultural capital translations have acquired into economic capital" through a series of rewriting operation, they undoubtedly contribute to disseminating foreign literary works in another culture and increase their value by generating "such diverse modes of reception as reviews, course adoption, and scholarly research" [5] and spawning films, games, comics, and television shows.

It is generally believed that retranslation can lengthen the life of a foreign work, but the duration of a work depends more on the ongoing rewritings away from translation and frequent reviews, interpretations, course adoption, fragmentary reading of each generation. And in the age of internet "when our common culture, however much we might wish it were not so, is less and less a book culture and more and more a culture of cinema, television, and popular music" [15], and more and more a culture of mobile phone, rewriters will face more challenges than ever, as they, besides text editing, have to take advantage of information technology to make non-print media renderings including versions of video, radio, TV, and online. And in the age when written text is to be dismantled and transformed into "an audio-visual world and a hypertext, audience will experience everything in the past which can be activated and come back to life with the flick of a click" [19].

\section{References}

[1] Armstrong, Richard H. 2008, p.171. "Classical Translations of the Classics: The Dynamics of Literary Tradition in Translation Epic Poetry.'In Translation \& Classic Identity Change in the History of Culture, ed. by Alexandra Lianeri and Vanda Zajko, 169-202. New York: Oxford University Press.

[2] Bastin, Georges L. 2004, p.6-7, p.5. “Adaptation.”In Routledge Encyclopedia of Translation Studies, ed. by Mona Baker, 5-8.
Shanghai: Shanghai Foreign Language Education Press.

[3] Zhou, Hongmin. 2013, p.39, p.41, p.38-49. Study of Translation: a Functional Perspective. Beijing: Science Publishing House.

[4] Bielsa, Esperança, and Susan Bassnet, 2011, p.87. Translation in Global News. Shanghai: Shanghai Language Education Press.

[5] Venuti, Lawrence. 2008, p.27, p.30. "Translation, Interpretation, Canon Formation.” In Translation \& Classic Identity Change in the History of Culture, ed. by Alexandra Lianeri and Vanda Zajko, 27-51. New York: Oxford University Press.

[6] Han, Hongju. 2011, p.122, p.113, p.117. History of Zhejiang Modern Novels. Hongzhou: Hongzhou Press.

[7] Gürçaglar, Şehnaz Tahir. 2009, p.233, p.234. "Retranslation." In Routledge Encyclopedia of Translation Studies (2nd edition), ed. by Mona Baker \& Gabriela Saldanha, 233-236. London: Routledge.

[8] Xu Jun. 1998, p.134. "There is no Likelihood of Final Version of Translation." In Reflection on Translation, ed. by Xu Jun, 133-138. Wuhan: Hubei Education Press.

[9] Zhuhai, Press (ed.). 2006, p.2, p.1. Robinson Crusoe. Zhuhai: Zhuhai Press.

[10] Chen, Fukang. 2000, p.303. Historical Manuscripts of Chinese Translation Theory. Shanghai: Shanghai Language Education Press.

[11] Xu, Xiacun (trans.). 1959, p.4. Robinson Crusoe. Beijing: People's Literature Publishing House.

[12] Tang, Yinsun (trans.) . 2010, p.6. Robinson Crusoe (illustrative edition) 鲁宾逊漂流记（插图本, Beijing: Central Edition \& Translation Press, 2010.

[13] Guo, Jianzhong (trans.). 1996, p.3, p. 6. Robinson Crusoe（《鲁 滨孙飘流记》) . Nanjing: Yilin Press.

[14] Lin Yian. 1998, p.156. “On Retranslation.” In Reflection on Translation, ed. by Xu Jun, 156-163. Wuhan: Hubei Education Press.

[15] Lefevere, Andre. 2007, p.2, p.3. Translation, Rewriting, and the Manipulation of Literary Fame. Shanghai: Shanghai Foreign Language Education Press.

[16] Zheng, Jian, and Zhang Bo (ed.). 2006, p.1. Robinson Crusoe (student edition), Beijing: China Foreign Translation and Publication Corporation.

[17] Zuo, Ruke (rewrite). 2009, p.1. Robinson Crusoe (student edition). Nanjing: Yilin Press.

[18] Editorial Board of World Literature (ed.). 2010, p.1. Robinson Crusoe. Yanji: Yanbian University Press.

[19] Tan Junwu. 2003. "Literary Cannon at the Age of Ubiquitous Network." Literary Theory and Criticism, 3: 80-83. 


\section{Biography}

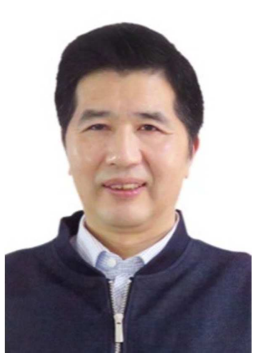

Zhou Hongmin, professor and director of Translation Study Institute of Nanjing Xiaozhuang University, standing director of Chinese Association for Translation, Interpreting and Cognition. He once served as translator and interpreter in a large state-run enterprise for three years. Ever since in universities he has been engaged in translation education and research. His academic interest includes cognition and translation, Chinese culture and translation, practical texts and translation, and up to now he has published 62 papers and 4 books, mostly concerning the study of the said subjects. 